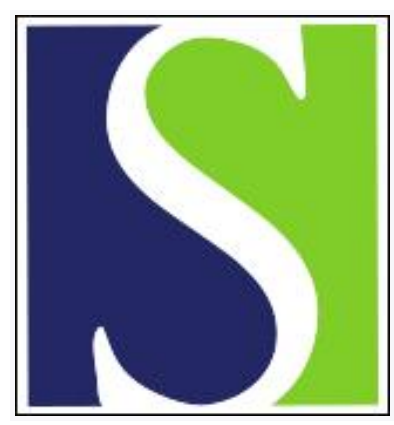

Scand J Work Environ Health 1992;18(6):388-392

https://doi.org/10.5271/sjweh.1558

Issue date: 01 Dec 1992

Work-related behavioral and dental risk factors among confectionery workers.

by Masalin $\mathrm{K}$, Murtomaa $\mathrm{H}$

Affiliation: Department of Dental Public Health, University of Helsinki, Finland.

This article in PubMed: www.ncbi.nlm.nih.gov/pubmed/1485164

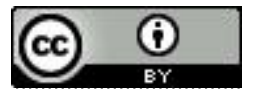




\title{
Work-related behavioral and dental risk factors among confectionery workers
}

\author{
Kai Masalin, DDS, Heikki Murtomaa, $\mathrm{PhD}^{1}$
}

\begin{abstract}
MASALIN K, MURTOMAA H. Work-related behavioral and dental risk factors among confectionery workers. Scand J Work Environ Health 1992;18:388 - 92. The dietary habits and dental health behavior of 294 employees in a Finnish confectionery company were studied to determine the reasons for their dental caries experience and their caries-promoting salivary microbiological findings. A diary and a questionnaire were used. A caries risk index was constructed for salivary microbiological findings. Daily dietary acidogenic exposures were calculated, and differences between low and high caries-risk groups were analyzed. Statistically significant differences in dietary habits between the low- and high-risk groups were found for the entire study population and for the men, the cookie makers, and the sweets makers. A significant positive correlation was found between untreated caries and the number of sugary meals. No differences were found in dental health behavior or dental knowledge between the study groups. The results show that the nature of between-meal snacks and confectionery workers' freedom to consume their products constitutes a potential hazard to dental health.
\end{abstract}

Key terms: dental caries, dental health behavior, diet, occupational diseases.

It has been shown that confectionery workers have poorer oral health than the population as a whole (1) and also poorer oral health than other industrial workers $(2-4)$. Sugar dust has been considered to be the main reason for the high incidence of caries among workers in the confectionery industry and bakeries $(1,5-7)$. However, recent studies have shown that in the modern confectionery industry there are very few jobs involving exposure to sugar dust in amounts needed to increase the risk of caries, at least in theory (8-10).

A comprehensive study (9) of the oral health status of workers in a modern Finnish confectionery factory (making cookies, sweets, and bakery products) showed that the workers' caries experience, measured using values of the standardized DMFS index, ${ }^{2}$ was highest on the cookie production line and lowest or second lowest on the sweets production line when compared with that of workers on other production lines and with that of an unexposed reference group from the same factory. Measurements of the hypothetical caries risk also showed that the lowest percentage of workers with a high risk of caries was related to sweets production.

Because the minimal or nonexistent exposure to sugar dust could not explain the differences in caries experience or in salivary microbiological findings between the groups, an attempt was made to explain the findings on the basis of other factors.

\footnotetext{
1 Department of Dental Public Health, Institute of Dentistry, University of Helsinki, Helsinki, Finland.

2 The DMFS index indicates the number of decayed (D), missing (M), and filled (F) tooth surfaces $(\mathrm{S})$.
}

Reprint requests to: Dr K Masalin, Suomen Hammashuolto Oy, Malmin Asematie 6, SF-00700 Helsinki, Finland
The aims of our study were (i) to study the dietary habits of workers on different production lines with respect to caries and salivary microbiological findings and to compare the results with those of a comparison group of workers not involved in production or units directly associated with sugary environments, (ii) to study the effect of dietary habits on caries risk as measured by a theoretical risk index, and (iii) to study the dental health behavior and conceptions of confectionery workers to collect data needed for possible preventive measures.

\section{Materials and methods}

\section{Subjects and referents}

The study population was selected from 700 workers in a Finnish confectionery factory (Fazer, Inc). One of every two or three employees, depending on the number engaged in the different tasks on each main production line, was selected, on a voluntary basis, from alphabetical lists of workers on each line. The production lines differed in respect to the work environment, worker behavior, and work hours. A comparison group was chosen from workers not involved in production or units directly associated with sugary environments. Only workers who had at least one tooth of their own were included. Altogether, 338 employees were selected. Forty workers were excluded from the final analysis because they did not return their dietary diaries, and four workers because of missing data concerning their gender. The results presented relate to 294 employees ( $87 \%$ of the sample). The distributions of the subjects by subgroup, base-line caries status, and salivary microbiological findings are shown in table 1 . 


\section{Clinical record}

The caries status of the study population was recorded with the use of the DMFS index. Saliva stimulated by paraffin wax was microbiologically analyzed from assessments of counts of salivary lactobacilli, Streptococcus mutans, and the presence or absence of Candida albicans with Dentocult-LB ${ }^{\circledR}$, Dentocult-SM ${ }^{\circledR}$, and Oricult- $\mathrm{N}^{\circledR}$ kits, respectively (Orion Diagnostica, Espoo, Finland). The methods used to assess oral health and the salivary analyses and to estimate examiner error have been reported elsewhere, with moredetailed clinical base-line data (9).

\section{Caries risk index}

A hypothetical caries-risk index was constructed on the basis of the saliva analysis results. Salivary lactobacilli and $S$ mutans counts over $10^{6}$ colony-forming units per milliliter and the presence of $C$ albicans were considered to indicate caries-promoting salivary characteristics. Each was given one point. The percentages of workers at low risk (index score 0 ) and high risk (index score 3 ) are shown in table 1.

\section{Questionnaire}

All of the subjects were given a pretested questionnaire on which to record their anamnestic data and work experience. The same questionnaire was employed to determine their use of dental services, reasons for their dental appointments, and their dental home-care habits. Opinions about the effects of their work environment on their dental health were also requested. The subjects' dental knowledge was determined with the help of a series of statements relating to the effects of fluorides, symptoms of gingivitis, the nature of dental calculus, anatomy of the tooth, and the cleansing effects of various fruits and vegetables. To compare the dental knowledge of the different groups, a den- tal knowledge index was constructed. Every correct statement was scored +1 , and every incorrect statement was scored $\mathbf{- 1}$. Total scores could therefore vary from +7 to -7 .

\section{Dietary analysis and the concept of a low salivary $\mathrm{pH}$ time}

A specially designed 7-d dietary diary was prepared for the study. Each worker was asked to keep the diary for one week, including the weekend. The workers recorded details of every meal, snack, sweet and drink, especially as regards its sugar content. Times of ingestion and daily frequencies of toothbrushing were also recorded. Consumption of more than six meals or snacks a day or over three sugar-containing food ingestions daily was considered poor dietary behavior, putting the subject at risk of caries. On the theoretical basis of a decrease in salivary $\mathrm{pH}$, which results from acid production from carbohydrates (11), the daily dietary acidogenic exposure time was estimated for the different groups.

\section{Statistical analysis}

The DMFS means of the groups were adjusted with regard to gender, age, and work years with the use of the analysis of covariance.

The significances of differences in the distributions of workers having risky dietary habits in the various groups were tested with the chi-square test. The significances of the differences in the mean numbers of meals and sugar-containing meals or snacks for subjects with different caries index values were tested with the two-tailed t-test.

The low salivary $\mathrm{pH}$ time was estimated to be 20 , 30 , or $40 \mathrm{~min}$ after any food ingestion. Three total, hypothetical daily acidogenic exposure times were therefore calculated for the different groups, and the

Table 1. Number, gender distribution, mean and adjusted mean DMFS index, mean DS index, and percentage of subjects with salivary microbiological findings indicating low (score 0 ) and high (score 3 ) caries risk. [DMFS index = index indicating number of decayed (D), missing (M), and filled (F) tooth surfaces (S); DS index = index indicating number of decayed (D) tooth surfaces (S)]

\begin{tabular}{|c|c|c|c|c|c|c|c|c|c|}
\hline \multirow{2}{*}{ Group } & \multirow{2}{*}{$\begin{array}{c}\text { Number } \\
\text { of } \\
\text { workers }\end{array}$} & \multicolumn{2}{|c|}{ Gender } & \multirow{2}{*}{$\begin{array}{l}\text { DMFS } \\
\text { index }\end{array}$} & \multirow{2}{*}{$\begin{array}{c}\text { DS } \\
\text { index }\end{array}$} & \multicolumn{2}{|c|}{$\begin{array}{l}\text { Adjusted DMFS } \\
\text { index }\end{array}$} & \multicolumn{2}{|c|}{$\begin{array}{l}\text { Salivary risk } \\
\text { factors }^{a}\end{array}$} \\
\hline & & $\begin{array}{c}\text { Male } \\
(\mathrm{N})\end{array}$ & $\begin{array}{c}\text { Female } \\
\text { (N) }\end{array}$ & & & $\mathrm{I}^{\mathrm{b}}$ & $\| \mathrm{lc}, \mathrm{d}$ & 0 & 3 \\
\hline $\begin{array}{l}\text { Cookie-making } \\
\text { Sweets } \\
\text { Bakery } \\
\text { Comparison }\end{array}$ & $\begin{array}{r}48 \\
116 \\
56 \\
74\end{array}$ & $\begin{array}{l}13 \\
25 \\
15 \\
27\end{array}$ & $\begin{array}{l}35 \\
91 \\
41 \\
47\end{array}$ & $\begin{array}{l}72.2 \\
62.2 \\
67.5 \\
59.8\end{array}$ & $\begin{array}{l}2.3 \\
1.8 \\
1.6 \\
2.3\end{array}$ & $\begin{array}{l}72.0^{\mathrm{e}} \\
58.2^{\mathrm{h}} \\
65.5 \\
60.7\end{array}$ & $\begin{array}{l}72.7^{\mathrm{f}} \\
58.2^{\mathrm{i}} \\
65.7^{-} \\
60.6\end{array}$ & $\begin{array}{l}22.9 \\
37.1 \\
25.0 \\
29.7\end{array}$ & $\begin{array}{l}22.9^{9} \\
10.3^{j} \\
26.8^{k} \\
12.2\end{array}$ \\
\hline
\end{tabular}

a The numerals 0 and 3 indicate caries risk based on the number of salivary acidogenic bacteria and yeasts. See the text for a detailed explanation. Note: The experimentwise type I error probability was $<0.07$.

b Adjusted with regard to gender, age, and total work time in the confectionery industry.

c Adjusted with regard to gender, age, and work years on the subject's current production line.

Note: The experimentwise type I error probability was $<0.05$.

e Difference, $P<0.05$, between the cookie-making and comparison groups.

$f$ Difference, $P<0.01$, between the cookie-making and comparison groups.

9 Difference, $\mathrm{P}<0.05$, between the cookie-making and sweets groups.

h Difference, $P<0.01$, between the cookie-making and sweets groups.

Difference, $P<0.001$, between the cookie-making and sweets groups.

I Difference, $P<0.01$, between the sweets and bakery groups.

$k$ Difference, $P<0.05$, between the bakery and comparison groups. 
significances of the differences between the groups were tested with the two-tailed t-test.

The significances of the differences between the groups at low risk of caries (caries risk index 0 ) and at high risk of caries (caries risk index 3 ) were also assessed with the two-tailed t-test, using the mean low salivary $\mathrm{pH}$ times.

Correlations between the mean numbers of meals and sugary meals and the numbers of decayed surfaces were studied in comparisons of the Pearson correlation coefficient values of the different groups.

The significances of the differences in the mean scores of the dental knowledge index of the various subgroups were tested with the two-tailed t-test.

The increase in probability of making one or more type I errors in multiple comparisons between the groups was controlled by the Bonferroni inequality method (12).

Table 2. Mean number of all daily and sugar-containing meals and snacks in various study groups with a 0 (low risk) or 3 (high risk) score for caries-promoting salivary characteristics.

\begin{tabular}{|c|c|c|c|c|c|}
\hline \multirow{2}{*}{ Group } & \multirow{2}{*}{$\mathrm{N}$} & \multicolumn{2}{|c|}{ All meals } & \multicolumn{2}{|c|}{ Sugary meals } \\
\hline & & Mean & SD & Mean & SD \\
\hline \multicolumn{6}{|l|}{ Men } \\
\hline $\begin{array}{l}\text { Risk score } 0 \\
\text { Risk score } 3\end{array}$ & $\begin{array}{l}21 \\
16\end{array}$ & $\begin{array}{l}7.3 \\
8.2\end{array}$ & $\begin{array}{l}1.9 \\
1.4\end{array}$ & $\begin{array}{l}4.2 \\
4.8\end{array}$ & $\begin{array}{l}2.1^{\mathrm{a}} \\
1.9\end{array}$ \\
\hline \multicolumn{6}{|l|}{ Women } \\
\hline $\begin{array}{l}\text { Risk score } 0 \\
\text { Risk score } 3\end{array}$ & $\begin{array}{l}69 \\
31\end{array}$ & $\begin{array}{l}7.1 \\
7.8\end{array}$ & $\begin{array}{l}1.7 \\
2.1\end{array}$ & $\begin{array}{l}3.1 \\
4.1\end{array}$ & $\begin{array}{l}1.4^{\star} \\
2.2\end{array}$ \\
\hline \multicolumn{6}{|l|}{ Cookie-making } \\
\hline $\begin{array}{l}\text { Risk score } 0 \\
\text { Risk score } 3\end{array}$ & $\begin{array}{l}11 \\
11\end{array}$ & $\begin{array}{l}6.4 \\
8.1\end{array}$ & $\begin{array}{l}1.4^{*} \\
1.9\end{array}$ & $\begin{array}{l}2.6 \\
4.6\end{array}$ & $\begin{array}{l}1.3^{* *} \\
1.7^{*}\end{array}$ \\
\hline \multicolumn{6}{|l|}{ Sweets } \\
\hline $\begin{array}{l}\text { Risk socre } 0 \\
\text { Risk score } 3\end{array}$ & $\begin{array}{l}43 \\
12\end{array}$ & $\begin{array}{l}7.3 \\
8.5\end{array}$ & $\begin{array}{l}1.6^{*} \\
2.3\end{array}$ & $\begin{array}{l}3.4 \\
4.6\end{array}$ & $\begin{array}{l}1.7 \\
2.5\end{array}$ \\
\hline \multicolumn{6}{|l|}{ Bakery } \\
\hline $\begin{array}{l}\text { Risk score } 0 \\
\text { Risk score } 3\end{array}$ & $\begin{array}{l}14 \\
15\end{array}$ & $\begin{array}{l}6.8 \\
7.4\end{array}$ & $\begin{array}{l}2.1 \\
1.9\end{array}$ & $\begin{array}{l}3.2 \\
4.3\end{array}$ & $\begin{array}{l}1.8 \\
2.5\end{array}$ \\
\hline \multicolumn{6}{|l|}{ Comparison } \\
\hline $\begin{array}{l}\text { Risk score } 0 \\
\text { Risk score } 3\end{array}$ & $\frac{22}{9}$ & $\begin{array}{l}7.4 \\
8.1\end{array}$ & $\begin{array}{l}1.9 \\
1.1\end{array}$ & $\begin{array}{l}3.8 \\
3.9\end{array}$ & $\begin{array}{l}1.6 \\
1.5\end{array}$ \\
\hline \multicolumn{6}{|l|}{ Allb } \\
\hline $\begin{array}{l}\text { Risk score } 0 \\
\text { Risk score } 3\end{array}$ & $\begin{array}{l}90 \\
\Delta 7 \\
\end{array}$ & $\begin{array}{l}7.1 \\
8.0 \\
\end{array}$ & $\begin{array}{l}1.7^{\circ} \\
1.9\end{array}$ & $\begin{array}{l}3.3 \\
4.3\end{array}$ & $\begin{array}{l}1.7^{* *} \\
2.1\end{array}$ \\
\hline
\end{tabular}

a Difference, $P<0.05$, between the men and women at low risk from sugary meals.

b All production-line groups and the comparison group combined. * $P<0.05,{ }^{*} P<0.01$, difference between the tow-risk (risk score 0 ) and high-risk (risk score 3 ) groups.

Table 3. Percentage of workers visiting a dentist at least every second year in the different groups. $(A=$ all subjects, $B=$ subjects who believed the work environment had adverse effects on their dental health)

\begin{tabular}{|c|c|c|c|c|c|c|}
\hline \multirow[b]{2}{*}{ Group } & \multicolumn{3}{|c|}{$A(N=284)$} & \multicolumn{3}{|c|}{$B(N=114)$} \\
\hline & $\begin{array}{c}\text { Men } \\
(N=78)\end{array}$ & $\begin{array}{l}\text { Women } \\
(N=206)\end{array}$ & All & $\begin{array}{c}\text { Men } \\
(N=29)\end{array}$ & $\begin{array}{l}\text { Women } \\
(N=85)\end{array}$ & All \\
\hline $\begin{array}{l}\text { Cookie-making } \\
\text { Sweets } \\
\text { Bakery } \\
\text { Comparison }\end{array}$ & $\begin{array}{l}76.9^{a} \\
60.9 \\
40.0 \\
63.0\end{array}$ & $\begin{array}{l}50.0 \\
50.0 \\
62.2^{c} \\
70.2^{c}\end{array}$ & $\begin{array}{l}57.4 \\
52.3^{\mathrm{b}} \\
55.8 \\
67.6\end{array}$ & $\begin{array}{r}100.0 \\
70.0 \\
40.0 \\
66.7\end{array}$ & $\begin{array}{l}58.3 \\
52.8 \\
70.6 \\
80.0^{\text {d }}\end{array}$ & $\begin{array}{l}70.6 \\
56.5 \\
63.6 \\
75.9\end{array}$ \\
\hline
\end{tabular}

a Difference between the cookie-making and bakery groups, $P<0.05$.

- Difference between the sweets and comparison groups, $P<0.05$.

c Difference between sweets and comparison groups, $P<0.05$

d Difference between the sweets and comparison groups, $P<0.05$.

\section{Results}

\section{Dietary habits}

Workers in the sweets group the most frequently $(80.2 \%)$ had more than six meals or snacks a day. Consumption of sugar-containing products more than three times a day was the most frequent in the cookie-making group $(\mathbf{7 5 . 0 \% )}$. The differences between the groups were not statistically significant. In general, the men ate more frequently than the women, and they significantly more frequently ate sugar-containing products [male workers 4.9 (SD 2.1) sugary meals a day, female workers 3.6 (SD 1.7) sugary meals a day] $(\mathrm{P}<0.001)$. Eighty-two percent of the men had more than three sugar-containing meals daily as compared with $58 \%$ of the women $(\mathrm{P}<0.001)$. This difference was statistically significant for all of the production line workers but not for the comparison group. The most common between-meal snacks were sugary soft drinks or coffee, pastries, and the products of the workers' own production lines.

\section{Diet and caries risk}

In terms of the calculated total daily duration of low salivary $\mathrm{pH}$ time, no statistically significant differences were found between the groups, although the men had longer total exposure than the women $(\mathrm{P}<0.05)$. On comparing the subjects at low (caries risk index 0 ) and high (caries risk index 3 ) risk of caries, we also found statistically significant differences in relation to low $\mathrm{pH}$ times for the entire study population $(\mathrm{P}<0.01)$, for the men, and for the cookie-making and sweets groups $(\mathrm{P}<0.05)$. When using the estimated $40-\mathrm{min}$ low $\mathrm{pH}$ time, we found the total mean acidogenic exposure per person to be 5.0 (range $2.6-9.1$ ) $\mathrm{h}$ a day, assuming that the subjects had $8 \mathrm{~h}$ of sleep.

A statistically significant positive correlation was found between untreated caries, as reflected by the decayed surface score of the DMFS index, and the number of sugary meals for the whole study population, including the comparison group [correlation coefficient $(\mathrm{r})=0.182, \mathrm{P}<0.05]$, and for the female workers $(r=0.203, P<0.05)$. In the different groups, the correlation was evident only for the bakery workers $(r=0.416, P<0.05)$.

All of the subjects with a high risk of caries (index value 3) reported eating more meals and also more sugar-containing meals daily than the subjects with a low risk of caries (index value 0 ) (table 2).

\section{Dental health behavior and conceptions}

About 40 (range 36-43)\% of the workers believed that their work environment had had adverse effects on their oral health. However, nearly the same percentage of workers (range 33-41\%) stated they did not know whether their work environment had any effects on dental health. Caries $(85 \%)$ and calculus formation 
$(31 \%)$ were the most frequently mentioned as adverse results of the current work environment.

One-half to two-thirds of the workers said they visited a dentist at least once in two years. The use of dental services did not seem to be influenced by the belief that the work environment adversely affected the subjects' oral health (table 3).

All of the workers in the cookie-making group and all of the female workers reported that they brushed their teeth at least once a day. The mean frequencies were 1.4 (SD 0.6) for the men and 1.7 (SD 0.6) for the women in the whole study population, the difference being statistically significant $(P<0.05)$.

A routine check-up was reported as the reason for the last dental visit by $36 \%$ of the workers. In the comparison group only $8 \%$ of the subjects reported toothache as the reason for a dental visit. The proportions for this response in the other groups varied from $21 \%$ in the bakery group to $29 \%$ in the cookie-making group. This difference between the comparison and other groups was statistically significant.

More than $80 \%$ of the workers in the different groups considered their dental fitness adequate, and they generally regarded their dental health as satisfactory. There were no statistically significant differences between the production-line groups in terms of the dental knowledge index. The mean scores were 1.3-1.4, individual scores varying between -1 and +3 .

\section{Discussion}

The concept of "'baker's caries" has been based on the results of some earlier studies which concluded that dental caries of typical appearance and location on flat surfaces of teeth can exist in confectionery workers and that the caries experience of confectionery workers is higher than in the normal population or in some other reference groups $(1,3,4,6,13)$. Despite the fact that sugar dust has frequently been blamed, in very few studies has exposure to sugar dust been measured or other reasons for sugar exposure studied in detail (7-9).

In our study dietary habits, not reported earlier in this connection, were determined with the help of a diary. The reliability of diary methods is naturally affected by the recorder. A self-administered diary has been considered more reliable than a diary obtained through interview (14). When a subject acts as his or her own recorder, there is danger however that habits may change during the study (15). Reliability is, however, increased by daily recording, which diminishes memory errors. The diary method is suitable when there is much detailed, time-related information to report (16), as in our study. The workers were promised an individual feedback of findings, and this promise probably helped to increase the number of diaries returned, and also their reliability. The percentage of diaries returned was high $(88 \%)$, and the distribution of dropouts from the different groups was fairly even.
These two factors increased the representativeness of the results.

It has been shown by many authors that the composition and contents of food or snacks correlate with caries risk. (See, for example, reference 17.) Bibby et al (18) found that foods with a high content of sugar were cleared more rapidly in the mouth and depressed the $\mathrm{pH}$ of plaque for shorter times than starchy foods containing less sugar. Pearce (19), in his caries prediction tests, found that a fruit and cereal snack bar supplemented with powdered milk produced more titratable acid but did not reach as low a terminal $\mathrm{pH}$ as a sweet cookie on in vitro fermentation by salivary organisms. In an intraoral test the bar caused significantly less enamel softening than the cookie. The statistically significant difference found in our study in the number of workers with low and high caries risk between the cookie-making and sweets groups and between the bakery and sweets groups further supports this finding.

In our study there was no statistically significant difference in the frequency of sugary meals between the cookie-making and sweets groups, but there was a difference in the adjusted DMFS figures between these groups (table 1). This fact and the finding that sweets were often included in between-meal snacks in the sweets group but only occasionally in the cookiemaking and other groups also suggest that starchy between-meal snacks can be a greater cariogenic threat to the dental health of confectionery workers than sweets. This result is supported by the results of Renz \& Bibby (20), who showed that even boiled potato created more acid in in vitro tests than pumpernickel bread (20).

As regards dental health behavior and knowledge, the study population did not differ from the ordinary Finnish population. Regular dental visits were made by a little more than half of the production workers and by almost $70 \%$ of the comparison group. These figures are of the same magnitude as those of the Finnish population as a whole (21) and those of Danish dock workers (22). The frequency of daily toothbrushing reported by the workers was almost the same as that found in a Finnish national survey $(90 \%)$ in 1990 (23). Most of the workers had a basic knowledge of calculus and of the symptoms of gingivitis, but this knowledge did not correlate with the use of dental services or tooth cleaning behavior, as shown previously $(21,24)$.

Previous findings have shown that sugar dust is no longer a serious environmental problem in the modern confectionery industry $(8-10)$. The present results show that dietary behavior and the nature of betweenmeal snacks seem to be the most significant dental risk exposures in the confectionery industry. The type of products manufactured by the workers and the fact that the workers are allowed to consume these products during workhours constitute potential hazards to the dental health of these workers. This situation should 
be seen as an occupational hazard and should be tackled accordingly. For instance, in caries-susceptible persons, between-meal consumption of starchy and sugarcontaining foods is an obvious risk factor that could easily be identified using modern salivary tests. If it is borne in mind that our subjects visited a dentist mostly for emergency treatment, although most of them had a basic knowledge of dental diseases and were also aware of the potential dental hazards, the need for simple and effective prophylactic measures in this branch of industry is obvious.

\section{Acknowledgments}

This study was supported by the Finnish Work Environment Fund and the Finnish Dental Society.

\section{References}

1. Andersson T, Larsson P-G. Kariesutbredningen hos bagare och konditorer i Malmö [Caries experience among bakers and pastry cooks in Malmö]. Odontol Rev 1967;18:303-7.

2. Anaize JZ. Prevalence of dental caries among workers in the sweets industry in Israel. Community Dent Oral Epidemiol 1978;6:286-9.

3. Holdt H. Forekomsten af tandsygdomme hos bagere og metalarbejdere [Dental health status among bakers and metal workers]. Tandlaegebladet 1982;86:639-8.

4. Petersen PE. Tandforholdene på en dansk chokoladefabrik: II. Tandsygdomsforekomst og behandlingsbehov [Dental health and treatment needs among chocolate workers]. Tandlaegebladet 1984;88:291-6.

5. Hesse F. Zahncaries bei Bäckern. Dtsch Monatsschr Zahnheilkd 1886;4:238-9.

6. Wohlauer E. Ueber Konditoren und ZuckerbäckerKaries und deren Prophylaxis. Zahnärztl Wochenbl 1896;10:15-6.

7. Petersen PE. Dental health among workers at a Danish chocolate factory. Community Dent Oral Epidemiol 1983;11:337-41.

8. Masalin K, Degerth R, Murtomaa H. Airborne sugar and flour dust in the Finnish confectionary industry. Appl Ind Hyg 1988;3:231-5.

9. Masalin K, Murtomaa H, Meurman JH. Oral health of workers in the modern Finnish confectionery industry. Community Dent Oral Epidemiol 1990;18:126-30.

10. Louhelainen $K$, Eskelinen $T$, Terho E O, Husman $K$, Kotimaa M, Sarantila R, et al. Pölyaltistus, hengitys- elinoireet ja lämpökuormitus elintarviketeollisuudessa [Dust exposure, respiratory symptoms and heat load in the foodstuff industry]. Kuopio (Finland): Kuopio Regional Institute of Occupational Health, 1989. (Series reports; no 3.)

11. Neff D. Acid production from different carbohydrate sources in human plaque in situ. Caries Res 1967;1: $78-87$.

12. Miller RG Jr. Simultaneous statistical inference. 2nd ed, New York, NY: Springer Verlag Inc, 1981:6-8.

13. Hals E. Karies' kliniske og rontgenologiske billede. [The clinical and radiographic appearance of dental caries]. In: Ericsson Y, ed. Nordisk lärobok i kariologi. Stockholm: Sveriges Tandläkarförbunds Förlagsförening upa, 1967:169.

14. Juster FT. The validity and quality of time use estimates obtained from recall diaries. In: Juster FT, Stafford FP, ed. Time, goods and well-being. Ann Arbor, MI: Institute of Social Research, University of Michigan, 1985: 63-91.

15. Bateson N. Data construction in social surveys. London: George Allen \& Unwin, 1984. (Contemporary social research series; no 10.)

16. Myllykangas M. Päiväkirjamenetelmä koettujen oireiden ja lääkkeiden käytön tutkimisessa [The diary method in studying symptoms experienced and the use of drugs]. Kuopio: University of Kuopio, 1986. (Original reports; no $2 / 1986$.)

17. Gustafson BE, Quensel CE, Lanke LS, Lundqvist C, Grahnen H, Bonow BE, et al. The Wipeholm dental caries study. Acta Odontol Scand 1954;11:232-364.

18. Bibby BG, Mundorff SA, Zero DT, Almekinder KJ. Oral food clearance and the $\mathrm{pH}$ of plaque and saliva. J Am Dent Assoc 1986;112:333-7.

19. Pearce EI. A comparison of the cariogenicity of two infant snack foods. Aust Dent J 1989;34:240-4.

20. Renz CL, Bibby BG. In vitro acid production from starch and sucrose in saliva. J Dent Child 1989;56: 267-9.

21. Murtomaa $H$, Laine $P$, Masalin $K$. Dental health practices among Finnish adults. Community Dent Health 1984;1:131-9.

22. Petersen PE. Dental visits, dental health status and need for dental treatment in a Danish industrial population. Scand J Soc Med 1983;2:59-64.

23. Murtomaa $\mathrm{H}$, Ainamo J. Trends in toothbrushing and awareness of periodontal condition among adult Finns. J Dent Res 1992;71 spec issue:abstract 771 .

24. Rayant GA. Relationship between dental knowledge and tooth cleaning behavior. Community Dent Oral Epidemiol 1979;7:191-4.

Received for publication: 6 April 1992 